\title{
A revision of the Indigofereae (Fabaceae) in Australia. 2. Indigofera species with trifoliolate and alternately pinnate leaves
}

\author{
Peter G. Wilson ${ }^{1}$ and Ross Rowe ${ }^{1,2}$
}

\begin{abstract}
${ }^{1}$ National Herbarium of New South Wales, Royal Botanic Gardens, Sydney NSW 2000, Australia ${ }^{2}$ present address: Department of the Environment, Water, Heritage and the Arts, GPO Box 787,

Canberra ACT 2601, Australia.
\end{abstract}

\begin{abstract}
The second part of a revision of the tribe Indigofereae (Fabaceae) occurring in Australia is presented, covering those species with consistently trifoliolate leaves and the pinnate-leaved species with leaflets alternate on the rachis. Ten species are considered here: five are introduced, four are native and one is endemic. A neotype is chosen for Indigofera glandulosa Wendl. and a lectotype for its synonym Psoralea leich hardtii F.Muell.
\end{abstract}

\section{Introduction}

In our first paper on Indigofereae in Australia (Wilson \& Rowe 2004) we revised Indigastrum and the simple or unifoliolate species of Indigofera. Here we consider a further set of species that fall into two broad groups: those with consistently trifoliolate leaves and those with alternate leaflets. Almost all the alternate leaflet group are introductions to Australia and, with one exception, the remaining species included in this paper are native but not endemic. The single endemic species, however, is clearly related to species that occur outside Australia.

\section{Characters}

Particular care should be taken with one of the introduced species that has alternate leaflets: Indigofera oblongifolia. This species has a low leaflet number (usually 1-3) and may be mistakenly assessed as being either unifoliolate or trifoliolate.

In this paper, hairs are described as sparse when they are well separated and the stem or leaf surface is clearly visible, as moderately dense when the hairs are separated by the length of one arm of the biramous hair (or thereabouts), dense when the arms overlap but do not fully conceal the epidermis, and very dense when the epidermis is completely concealed. 


\section{Trifoliolate Species}

The trifoliolate species fall into two groups morphologically, although both groups lack a feature commonly found in Indigofera: endocarp spots. The first group, of two species, is characterised by having conspicuous discoid glands on the lower surface of the leaflets. These species are currently placed in section Laxiflorae Wight \& Arn. although it should be noted that similar glandular structures occur in other sections (Schrire 1995). A common feature of the second pair of species is the distinctive 4-angled fruit, which is a diagnostic, but not unique, attribute of section Tetragonocarpae Wight \& Arn. The latter section also contains a number of species with pinnate leaves, including the Australian I. ewartiana Domin, so this section is not restricted to species with trifoliolate leaves.

When working the following key, users should be aware that a few species with pinnate leaves occasionally have some trifoliolate leaves, but leaves with 5 or more leaflets are always present. These species are: I. boviperda (inland populations), I. georgei s. lat., $I$. ewartiana (see Wilson \& Rowe 1994) and some intergrades between I. schultziana and I. saxicola.

\section{Key to trifoliolate species}

1 Discoid glands on lower surface of leaflets conspicuous ............................................................... 2

1 Discoid glands on lower surface of leaflets absent .......................................................................... 3

2 Leaves pinnately trifoliolate (rachis extended 2.5-4.5 mm); discoid glands brown to black; fruit 5-6 $\mathrm{m}$ long, 2-seeded I. glandulosa

2 Leaves \pm digitately trifoliolate (rachis extended only c. $1 \mathrm{~mm}$ ); discoid glands orange; fruit usually 7-15 mm long, 3-9-seeded

I. trifoliata

3 Inflorescences mostly $<40 \mathrm{~mm}$ long, shorter than the leaf I. trita

3 Inflorescence mostly $>40 \mathrm{~mm}$ long, longer than the leaf I. polygaloides

Indigofera glandulosa Wendl., Bot. Beob. 55 (1798)

Type citation: 'Vaterland: Ostindien. $\odot$ '

Neotype (designated here): 'Ind. Or. Roxburgh 1789' (Smith Herbarium, sheet 1213.16, LINN, right-hand specimen)

Indigofera glandulosa Roxb. ex Willd., Sp. Pl. 3(2) : 1227 (1803)

Type citation: 'Habitat in India orientale. $\odot$ (v.s.)'

Type: Klein 750, 19 Nov 1794 (B-W, photo seen)

Psoralea leichhardtii F. Muell., Fragmenta 4: 22 (1863)

Type citation: 'Ad flumen Comet River. Dr. L. Leichhardt. D. Bunce.'

Lectotype (designated here): Queensland: Comet River, Leichhardt 446, [1847] (MEL 585912). Probable isolectotype: K

Illustration: de Kort \& Thijsse (1984) fig. 2q [fruit].

Erect annual or short lived perennial herb, $0.2-0.7 \mathrm{~m}$ high, with taproot; young stems ridged, green to yellowish or brown, hirsute with dense, spreading, unequally biramous hairs. Leaves pinnately trifoliolate; stipules narrow and triangular, $1.5-3 \mathrm{~mm}$ long, 
glabrescent, not spinescent, not persistent; petiole 9-21 mm long; rachis furrowed; multicellular hairs between leaflet pairs absent or sparse, inconspicuous, orange, clubshaped. Leaflets opposite; stipellae absent; lamina narrow to broadly obovate, $8-37 \mathrm{~mm}$ long, 3.5-17 mm wide; upper surface green; with sparse to moderately dense spreading hairs; lower surface grey to green with conspicuous light brown to black discoid glands and moderately dense spreading hairs; apex obtuse and shortly mucronate; veins not prominent. Inflorescences 5-20 mm long, shorter than leaves; peduncle $0.5-1 \mathrm{~mm}$ long; bracts linear to narrowly triangular, $0.7-1.1 \mathrm{~mm}$ long; flowers pink to purple or red; pedicel 0.9-1.5 mm long. Calyx 1.5-2.4 mm long; lobes subequal, longer than the length of the tube and covered with moderately dense, white to brown, shortly spreading hairs. Standard pink to red, elliptical to obovate, 3-3.7 mm long, $1.9-2.1 \mathrm{~mm}$ wide. Wings spathulate, $2.5-3.6 \mathrm{~mm}$ long, $0.8-1.1 \mathrm{~mm}$ wide. Keel 3.2-3.8 mm long, $1.2-$ $1.4 \mathrm{~mm}$ deep; lateral pockets $0.5-1.1 \mathrm{~mm}$ long; apex acute to rounded; hairs moderately dense, hyaline to brown, at the tip and along the bottom. Staminal tube $2.4-3.2 \mathrm{~mm}$ long, colourless. Ovary densely hairy. Pod spreading to deflexed, shortly cylindrical with membranous, toothed wings, 5-6 mm long, $2.5 \mathrm{~mm}$ wide, brown, hirsute; hairs sparse to moderately dense, somewhat spreading; apex shortly pointed; endocarp not spotted; seeds 2 per fruit.

Notes: Wendland's type of Indigofera glandulosa has not been located. De Kort \&Thijsse (1984) cite the type as 'Herb. Wendland (Hannover, destroyed)' but Stafleu and Cowan (1988) indicate that Wendland's types are at Göttingen (GOET). We have enquired at Göttingen but the type of this taxon was not found in that herbarium (Jochen Heinrichs, pers. comm. 2007). De Kort and Thijsse (1984: 120) further suggest that Wendland's type may have been a duplicate of the collection used by Willdenow when he later published the same name. These authors say 'Willdenow referred to Roxburgh, who wrote this name on the herbarium label' but this is not quite correct. Willdenow attributed the name to Roxburgh but the specimen itself was collected by Johann Gottfried Klein (an associate of Roxburgh's) in November 1794. Furthermore, judging from Willdenow's annotation, this specimen appears only to have reached Europe in 1802. On the other hand, the Roxburgh specimen in the Smith Herbarium (at LINN) is dated 1789 and is more likely to represent a duplicate of material Wendland may have seen. This seems a plausible scenario, but the uncertainties surrounding typification of this taxon have led us to choose one element on the sheet at LINN as neotype rather than as lectotype.

The MEL specimen of Psoralea leichhardtii, despite not having Mueller's binomial on the label, has been chosen as lectotype since it bears Leichhardt's own collecting tag. The sheet at K, ex Herbarium Hookerianum but originally from Mueller's herbarium, does have Mueller's binomial on the label but also contains a packet of fragments from a later collection by P.A. O'Shanesy. The two Leichhardt specimens are almost certainly part of a single gathering. Daniel Bunce, cited by Mueller as co-collector, was a gardener and botanist who accompanied Leichhardt on his second journey, but no reference to him can be found on either specimen, or any other specimen of this taxon. Bunce (1859) published an account of this expedition and reports that Leichhardt's party was in the vicinity of the Comet River twice. The first time was between February 13 and March 4, 1847, and Bunce (1859: 138) records that he collected 'several Leguminous plants having pink blossoms' on February 18, which may have included this species. On the return trip, they traversed the same region between 22 June and 3 July of the same 
year but Bunce (1859: 195) records that they travelled in 'forced and hurried stages', so it is less likely the type was collected then.

Distribution and habitat: in Australia this species has been found at scattered locations in Queensland, the Northern Territory and Western Australia; it is recorded on dark brown clay loams, frequently on land under cultivation. Although apparently rather rare (it hasn't been collected in Australia for around 30 years), its occurrence on cultivated land has led to its designation as a weed (Lazarides et al. 1997). The species is here accepted as native to Australia, although with some doubt; it is also known from India and Indonesia where it is recorded from similar habitats.

Selected specimens: Queensland: Leichhardt: Lenton Downs, about 50 miles WNW of Nebo, Johnson 2311, 8 May 1962 (BRI); Clermont district, Wilkins 2, 9 Mar 1943 (BRI); Buckleton, Springsure, McLaughlin s.n., May 1943 (BRI 232751). North Kennedy: Cashmere, Armit 155, 20 Mar 1875 (MEL 586621); Cunjuboy Station, between Hughenden and Mt Garnet, A. Wilson s.n., 10 Mar 1952 (BRI). Port Curtis: Neerkool Creek, Bowman 15, 1862 (MEL 585910); Alton Downs, near Rockhampton, Blank s.n., Apr 1921 (BRI 232752). South Kennedy: Logan Downs, Clermont, Bowden 2, Mar 1958 (BRI). Western Australia: Gardner: Block 68, sugar cane experimental area, Dept. Agriculture, Kununurra, Aplin 6285, 10 Mar 1978 (PERTH, NSW). Northern Territory: Darwin \& Gulf: 4 miles NW of Katherine, I. Wilson 49, 2 Jan 1965 (DNA); Old Station Springs, Mountain Valley Stn, Swinbourne 712, 26 Feb 1963 (CANB, MEL, NSW).

Indigofera polygaloides M. Scott, Kew Bull. June 1915: 88 (1915) non Gagnepain (1916)

Holotype: Northern Territory: Pine Creek, C.E.F. Allen 85, Feb 1914 (K, photo seen). Possible isotype: NSW

I. amaliae Domin, Biblioth. Bot. 89: 188 (1928)

Lectotype (see Wilson \& Rowe 1994: 643): Queensland: [Rockhampton] Dietrich 1854, [Feb 1866] (PR 527202). Isolectotypes: PR 527203, HBG, CANB 282834, MEL.

Prostrate or trailing perennial herb, $0.1-0.3 \mathrm{~m}$ high, with thickened or swollen taproot; young stems ridged, green, strigose with moderately dense, appressed, equally biramous hairs. Leaves trifoliolate; stipules narrowly triangular or linear, (1-)2-4 mm long, sparsely pubescent, not spinescent, persistent but not thickened or woody; petiole 3-13 mm long; rachis furrowed; multicellular hairs between leaflet pairs absent. Leaflets opposite; stipellae rarely absent to usually inconspicuous, $0.3-1 \mathrm{~mm}$ long; lamina elliptical to obovate, 5-15(-24) mm long, 3-10(-14) mm wide; upper surface green, with sparse to moderately dense, somewhat spreading, unequally biramous hairs; lower surface green (paler than above), with sparse to moderately dense, appressed, equally biramous hairs; apex obtuse and apiculate; veins not prominent. Inflorescences (15-)40-120(-360) $\mathrm{mm}$ long, longer than leaves; peduncle 5-20(-39) mm long; bracts triangular, $0.5-2 \mathrm{~mm}$ long; flowers pink to purple; pedicel $0.5-1 \mathrm{~mm}$ long. Calyx (2-)2.5-4 mm long; lobes subequal to equal, longer than the length of the tube and covered with moderately dense, white, appressed hairs. Standard pink, obovate, $4-5 \mathrm{~mm}$ long, 3.2-4.7 $\mathrm{mm}$ wide. Wings narrowly obovate to spathulate, $4-5.5 \mathrm{~mm}$ long, $1.3-2 \mathrm{~mm}$ wide. Keel $4.5-5 \mathrm{~mm}$ long, $1.2-2 \mathrm{~mm}$ deep; apex rounded; lateral pockets $0.5-1.2 \mathrm{~mm}$ long; hairs sparse, hyaline to white, along the bottom; margin ciliate. Staminal tube 3-4 mm long, colourless. Ovary glabrous to sparsely hairy. Pod ascending to descending, terete with lateral ridges, (10-)20-30 mm long, 1.5 $\mathrm{mm}$ wide, brown, strigose to glabrescent; hairs sparse to moderately dense, appressedapex acute, sometimes kinked upwards; endocarp not spotted. Seeds $7-10$ per fruit. 
Note: see Wilson and Rowe (1994) for discussion of typification and variation.

Distribution: Queensland, Northern Territory, and Western Australia (see Wilson \& Rowe 1994: fig. 2); it is found on stony slopes or plains and generally sandy soils in open woodland or sometimes in cleared areas.

Conservation status: Albrecht et al. (1997) suggest a coding of $3 \mathrm{k}$ for this species indicating that it is poorly known in the Northern Territory. However, I. polygaloides does not appear on the current Threatened Species List for the Northern Territory.

This taxon is still under-collected across its range and there have been no recent collections from the North Kennedy and Leichhardt districts of Queensland. Without assessment of the extent of populations and potential threats, this taxon should be considered 'Data Deficient' under current IUCN criteria (IUCN 2001).

Selected specimens: Queensland: Cook: Horn Island, Clarkson 6477, 10 Apr 1986 (BRI, MBA, NSW); $10 \mathrm{~km}$ south of the Palmer River crossing on the Peninsula Development road, Clarkson 6667 \& McDonald, 4 Mar 1987 (BRI, MBA, NSW, QRS). Port Curtis: 'Nullegar', about 2 km west of house, Anderson 854, 19 Apr 1979 (BRI); 'The Springs', 20 km N of Glen Geddes, Anderson 2944, 2 Mar 1982 (BRI); State Forest 473, Forster 16304, 19 Feb 1995 (BRI, NSW). North Kennedy: Bowen River, unknown coll., no date (MEL). Leichhardt: Peak Downs, Mueller s.n., (MEL, NSW). Western Australia: Gardner: behind Paspaley pontoon in Port George, Mitchell 2328 \& Willing, 6 Apr 1992 (NSW, PERTH); Water Supply Creek, Freshwater Bay, Mitchell 2874, 23 Mar 1993 (NSW, PERTH). Northern Territory: Darwin \& Gulf: 4 miles [c. 6.4 km] SW Stapleton Railway Siding, Muspratt 104, 4 Mar 1963 (DNA, MEL, NSW); 40 miles [c. 64 km] E Pine Creek, Byrnes 1342, 29 Jan 1969 (DNA); 2 km E of Bark Hut, Cowie 1377 \& Booth, 8 Feb 1991 (NSW); near Truant Island lighthouse, Mitchell 6751, 26 Apr 2001 (CANB, DNA, NSW).

Indigofera trifoliata L., Cent. Pl. 2: 29 (1756)

Lectotype (see Sanjappa in Turland and Jarvis 1997: 474): India, Herb. Linn. 923.3, right-hand plant (LINN, photo seen)

Anila trifoliata (L.) Kuntze, Rev. Gen. Pl. 2: 940 (1891)

Illustration: Banks and Solander (1900) t. 56.

Erect or spreading, rarely prostrate or trailing, perennial herb or subshrub, 0.3-0.6(1.2) $\mathrm{m}$ high, with woody rootstock or taproot; young stems ridged, green, strigose with dense, appressed, equally or unequally biramous hairs. Leaves digitately trifoliolate, very rarely 5-foliolate; stipules linear, 0.6-0.9 mm long, pubescent, not spinescent, not persistent; petiole 5-14 mm long; rachis furrowed; multicellular hairs between leaflet pairs sparse, inconspicuous, orange to red or brown, pointed-linear. Leaflets opposite; stipellae inconspicuous, $0.2-0.5 \mathrm{~mm}$ long; lamina obovate often narrow and elliptical to oblanceolate, (7-)12-30(-37) $\mathrm{mm}$ long, (2-)2.5-8.5(-11.5) $\mathrm{mm}$ wide; upper surface green, with sparse, appressed or shortly spreading hairs; lower surface green, with sparse, appressed hairs and conspicuous, yellow discoid glands; apex obtuse or acute and shortly mucronate; veins not prominent. Inflorescences $3.5-8(-13.5) \mathrm{mm}$ long, shorter than leaves; peduncle $0-0.5 \mathrm{~mm}$ long; bracts ovate, $0.3-0.6 \mathrm{~mm}$ long; flowers red; pedicel 0.4-0.9 mm long. Calyx 1.5-2.6 mm long; lobes subequal, longer than the length of the tube and covered with moderately dense, white to pale brown, appressed hairs. Standard red, ovate to obovate, 3.3-5 mm long, 2.4-3.4 mm wide. Wings \pm glabrous, $3.3-5 \mathrm{~mm}$ long, $1.1-1.8 \mathrm{~mm}$ wide. Keel $3.7-5 \mathrm{~mm}$ long, $1.4-1.7$ $\mathrm{mm}$ deep; lateral pockets $0.7-1.3 \mathrm{~mm}$ long; apex acute or rounded; hairs moderately dense, hyaline or brown, at the tip and along the bottom, interspersed with numerous 
discoid glands; margin ciliate. Staminal tube (2.2-)2.7-3.3 mm long, colourless. Ovary moderately hairy; discoid glands present on the ventral surface; style long, to c. $2.5 \mathrm{~mm}$. Pod descending, terete, with four narrow wings (one on either side of each suture), (5-)7-15(-20) mm long, 1-1.5 mm wide, brown, glabrescent, or strigose; hairs sparse, appressed (discoid glands also present); apex shortly beaked; endocarp not spotted; seeds 3-7 per fruit.

Notes: Endo and Ohashi (1998) found that I. trifoliata can be readily divided into two groups based on staminal tube length $(1.7-3.2 \mathrm{~mm}$ vs. $4.0-6.0 \mathrm{~mm}$ ) and style length (0.6-2.9 $\mathrm{mm}$ vs. $3.3-5.3 \mathrm{~mm})$ with very few intermediates. These authors did not, however, examine the type specimen. Staminal tubes and styles on the type specimen have been measured and found to be long (c. 4.5-5 and c. $4 \mathrm{~mm}$ long respectively), so populations in Australia do not match the type in this respect.

For other synonyms of I. trifoliata sens. lat., see de Kort and Thijsse (1984) and Endo and Ohashi (1998).

Distribution and habitat: Queensland, Northern Territory, and Western Australia; it is found in woodland, open forest or grassland. It is recorded from a range of substrates: gravelly or clay loams, black soil flats, river alluvium, skeletal soils on sandstone, and metamorphic or lateritic hill slopes. Outside Australia, the species is recorded from Pakistan to South China, Malesia and New Guinea.

Judging from the specimens seen, this species is now less widespread in Australia than it was in the late nineteenth and early twentieth centuries. This is particularly true for the subtropical part of its recorded range; there have been few recent records for many of the more southern regions of Queensland.

Selected specimens: Queensland: Burke: Sweers Island, Henne s.n. (MEL 586300). Burnett: Mount Perry, Keys s.n. (BRI 233639). Cook: Thursday Island, on road up Green Hill, Clarkson 6368, 8 Apr 1986 (BRI); $12.6 \mathrm{~km}$ SE of Mt Janet on the survey road along the Great Dividing Range, 11.5 km SW of Lakeland Downs township, Clarkson 5954, 4 June 1985 (BRI, MEL, NSW); $2.2 \mathrm{~km}$ SW of Archer Creek on the Ravenshoe to Mount Garnet road, Clarkson 3661, 17 Mar 1981 (BRI, NSW). Moreton: Goodna, Simmonds s.n., 27 Apr 1889 (BRI 233643). North Kennedy: Cashmere, Armit 156, 20 Mar 1875 (MEL 586620); Burdekin River area above Dalbeg on track to Gorge Weir, 20.9 km S of Expedition Pass Creek bridge, Staples 2116, 16 Apr 1975 (BRI, CANB); Ayr, Blake 8332, 28 Mar 1935 (BRI, CANB). Port Curtis: Nagoorin, Boyne Valley Line, Kahler s.n., 21 Oct 1935 (BRI 233646); South Percy Island, Tryon s.n., 5 Mar 1906 (BRI 233645). South Kennedy: Calen, Preller s.n., 21 Jan 1935 (BRI 233650). Wide Bay: State Forest 50, Glenbar, 3 km WSW of Mt Urah summit, Forster 13121 \& Machin, 27 Feb 1993 (BRI, NSW, MEL). Western Australia: Gardner: Mitchell Falls track, Wilson 313 \& Jacobs, 31 May 1988 (NSW, PERTH, L); King-ana, S end of Vansittart Bay, Mitchell 2899, 24 Mar 1993 (NSW); Careening Bay, Port Nelson, Kenneally 10067, 30 May 1987 (PERTH). Northern Territory: Darwin \& Gulf: Dalywoi Bay, Gove, Russell-Smith 4666,10 Feb 1988 (DNA); Kapalga, Dunlop 6068 \& Taylor, 9 Mar 1982 (NSW); Coomalie Creek, c. 40 miles [64 km] SE of Darwin, Muspratt 208, 18 Jan 1963 (DNA, BRI, NSW); Cobourg Peninsula, Trepang Bay, Cowie 3636, 18 Apr 1993 (BRI, CANB, NSW, PERTH); Fossil Head, Leach 4215, 23 Feb 1994 (NSW).

Indigofera trita L.f., Suppl. 335 (1782) subsp. trita

Holotype: 'Habitat in India' (LINN 923.9, photo seen)

Anila trita (L.f.) Kuntze, Rev. Gen. Pl. 2: 940 (1891) 
I. timorensis DC., Prod. 2 : 223 (1825)

Type Citation: '? in ins. Timor' (holo G-DC, n.v.; NSW microfiche)

Erect, annual or short lived perennial herb, 0.15-0.45 m high, with taproot; young stems ridged, green to grey, strigose with moderately dense to dense, appressed, equally biramous hairs. Leaves trifoliolate; stipules linear or narrow and triangular, (1.0-)1.5-3 $\mathrm{mm}$ long, pubescent, not spinescent, generally not persistent; petiole (1.5-)4-10(-15) $\mathrm{mm}$ long; rachis furrowed; multicellular hairs between leaflet pairs absent or sparse (only 2-3), inconspicuous, orange, pointed-linear; stipellae absent; lamina elliptical to obovate, (5-)8-20(-25) mm long, (2.0-)2.5-7(-10) mm wide; upper and lower surface green to grey, with moderately dense (rarely sparse) appressed hairs; apex obtuse and shortly or inconspicuously mucronate; veins not prominent. Inflorescence (5-)10-35(50) $\mathrm{mm}$ long, shorter than to longer than leaf; peduncle $0.5-3(-5.0) \mathrm{mm}$ long; bracts narrowly ovate, $0.5-1.5 \mathrm{~mm}$ long. Flowers dull or pale red; pedicel $0.5-1 \mathrm{~mm}$ long; calyx 2.5-5 mm long; lobes subequal, longer to much longer than the length of the tube and covered with moderately dense, grey, appressed hairs; standard red, elliptical to obovate, 5-6 mm long, 3.5-4.5 mm wide; wing narrowly obovate to spathulate, 5-6 $\mathrm{mm}$ long, 1.5-2.3 mm wide; keel 5-5.7 mm long, 1.5-2 mm wide, with lateral pockets 0.5-0.9 mm long, rounded apex, and sparse, hyaline or white hairs along the bottom; staminal tube 3-4 mm long, colourless; ovary sparsely or moderately hairy (becoming dense when fruit young). Pod spreading to descending, the pedicel strongly downturned and the fruit standing out at a pronounced angle, terete with a longitudinal ridge along each side of the pod, giving a 4-angled appearance, (8-)20-30 mm long, 2-3 mm wide, yellowish to pale brown, strigose; hairs moderately dense, appressed; apex shortly beaked or pointed; endocarp not spotted; seeds (2-)8-10 per fruit.

Notes: stipellae are apparently absent, although the 1-2 multicellular hairs recorded here may be much reduced stipellae that are up to $0.1 \mathrm{~mm}$ long only.

See Wilson \& Rowe (1994) for specimen citations and discussion of variation in Indigofera trita sens. lat. See de Kort and Thijsse (1984) for full synonymy.

Distribution and habitat: Queensland, Northern Territory, and Western Australia (see Wilson \& Rowe 1994: fig. 1); it is found in a wide range of habitats: cracking clay, rich loamy or sandy soils on open plains or amongst rocks of various types on hills. Also found in Pakistan, India, Sri Lanka, Burma \& Indonesia.

\section{Species with alternate leaflets}

The species with alternate leaflets also fall into two groups morphologically. The first group, of two species, is characterised by having short pods that rarely exceed $10 \mathrm{~mm}$ in length. These species also lack endocarp spots. They are currently placed in section Brachycarpae Wight \& Arn. This section also includes the simple-leaved species I. linifolia and I. cordifolia. The second set, of four species, can show other features similar to those in the first two species, particularly scarious stipule margins, and two of them also lack endocarp spots. These four species have been classified in section Alternifoliolae Harv. 


\section{Key to species with alternately pinnate leaves}

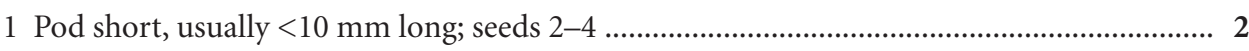

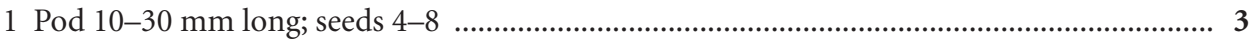

2 Sepals distinctly fused at base, to $0.5 \mathrm{~mm}$ wide; seeds usually 2 ; keel 3.5-4.5 mm long; staminal tube 2.5-3.2 $\mathrm{mm}$ long I. linnaei

2 Sepals only slightly fused at base, to $0.2 \mathrm{~mm}$ wide; seeds $2-4$; keel $2.7-3.0 \mathrm{~mm}$ long; staminal tube $1.5-1.8 \mathrm{~mm}$ long I. sessiliflora

3 Pods straight 4

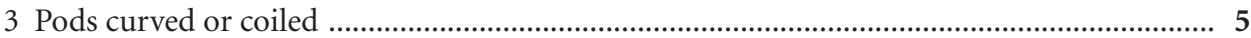

4 Pod 22-27 mm long (including a distinct beak 1.5-2.5 mm long); inflorescence over $120 \mathrm{~mm}$ long; leaflets 7-10, obovate to elliptical; staminal tube 3.5-4.0 $\mathrm{mm}$ long .... I. hendecaphylla

4 Pod 10-18 mm long with a short, blunt tip $0.5 \mathrm{~mm}$ long; inflorescence to $80 \mathrm{~mm}$ long; leaflets 5-7, obovate; staminal tube $2.3-3.2 \mathrm{~mm}$ long I. spicata

5 Plants erect; leaflets 1-4, 10-18 mm long; pods curved I. oblongifolia

5 Plants prostrate; leaflets 4-7, 3.5-9.5 mm long; pods coiled I. circinella

${ }^{\star}$ Indigofera circinella Baker f., J. Bot. 44: 314 (1906)

Holotype: Kenya: Scott Elliot 6892 (BM, n.v.). Isotype: K, n.v.

Prostrate perennial herb, less than $5 \mathrm{~cm}$ high, branches to $50 \mathrm{~cm}$ long or more, with taproot; young stems ridged or flattened, pale green, pubescent with sparse, appressed, equally biramous hairs plus some multicellular hairs. Leaves pinnate, (4-)6(-7)-leaflets; stipules triangular, 1.5-2.5 mm long, with scarious margin and narrow, red-brown, club-shaped multicellular hairs, glabrescent, not spinescent, persistent; petiole 0.5$1 \mathrm{~mm}$ long; rachis furrowed; multicellular hairs at the base of the petiolule sparse, inconspicuous, red to brown, club-shaped. Leaflets alternate, stipellae absent; lamina cuneate or obovate, 3-10 mm long, 1.5-3.5 mm wide; upper surface green, glabrous; lower surface green, with sparse, appressed hairs; apex obtuse and mucronate; veins not prominent. Inflorescences 4-10 mm long, shorter than leaves; peduncle 1-2 mm long; bracts ovate, $1 \mathrm{~mm}$ long; flowers pink to orange-red; pedicel $0.5-1 \mathrm{~mm}$ long. Calyx 2.5-3 mm long; lobes subequal to equal, longer than the length of the tube and covered with moderately dense, white appressed hairs. Standard pink, broadly obovate, 2.5-3 mm long, 2.5-3 mm wide. Wings spathulate, $3 \mathrm{~mm}$ long, 0.5-1 mm wide. Keel 2.5-3.5 mm long, $1 \mathrm{~mm}$ deep; lateral pockets $0.3-0.5 \mathrm{~mm}$ long; apex acute; glabrous or with very occasional hyaline to white hairs at the tip. Staminal tube $2-2.5 \mathrm{~mm}$ long, colourless. Ovary densely hairy. Pod deflexed, circinate and somewhat torulose, 15-25 mm long, 1.5-2 mm wide, brown, pubescent; hairs sparse to moderately dense, appressed; apex upturned and shortly beaked with persistent style; endocarp with pale orange spots. Seeds 6-14 per fruit.

Distribution: Queensland; recently naturalised in Brisbane. Native of Africa.

Selected Specimens: Queensland: Moreton: Coorparoo [suburb of Brisbane], Guymer 1873 \& Sharpe, 17 Feb 1984 (BRI, CANB, MEL, NSW); Chapel Hill Reservoir, Fleming Road, Bean 12762, 14 Dec 1997 (BRI, NSW). 
${ }^{\star}$ Indigofera hendecaphylla Jacq., Coll. Bot. 2: 358 (1788)

Indigofera endecaphylla auctt., orth. var.

Holotype: West Africa: 'Guinea’, cultivated Vienna. (W, fide Du Puy et al. 1993)

Indigofera spicata auctt.

Illustration: Morton (1989) figs 1-3, as I. spicata; Du Puy et al. (1993) Fig. 1, F-K.

Spreading, perennial herb or subshrub, (0.2-) 0.4-0.6 m high, with taproot; young stems \pm flattened and ridged, green or yellowish, strigose with sparse, hyaline to white, appressed, equally biramous hairs. Leaves pinnate, 7-10 leaflets, 20-55 mm long; stipules triangular with scarious margins, 5-7.5 mm long, glabrescent, not spinescent, persistent; petiole 1.5-5 mm long; rachis furrowed; multicellular hairs at the base of the petiolule absent. Leaflets alternate; stipellae absent or inconspicuous, $0.2-0.6 \mathrm{~mm}$ long, hair-like; lamina obovate to elliptical, 5-16 mm long, 2.5-7 mm wide; upper surface dull green, glabrous; lower surface green, with sparse to moderately dense, appressed hairs; apex obtuse and mucronate; veins not prominent. Inflorescences 120-150 mm long, longer than leaves; peduncle 10-20(-25) $\mathrm{mm}$ long; bracts ovate to triangular (margin scarious), 1.2-2.5 mm long; flowers red; pedicel $0.3-0.7 \mathrm{~mm}$ long. Calyx 2.5-4 mm long; lobes longer than the length of the tube, subequal, $1.5-3 \mathrm{~mm}$ long and covered with moderately dense, white, appressed hairs. Standard red, obovate, 3.8$4.9 \mathrm{~mm}$ long, 2.5-3.7 mm wide; hairs sparse to moderately dense, hyaline to white; apex obtuse. Wing oblong to spathulate, 3.7-4.5 mm long, 0.5-1.1 mm wide. Keel 3.9$4.4 \mathrm{~mm}$ long, $1-1.3 \mathrm{~mm}$ deep; lateral pockets $0.3-0.5 \mathrm{~mm}$ long; apex rounded; glabrous or with sparse, hyaline hairs; margin ciliate. Staminal tube 3.5-4 mm long, colourless. Ovary moderately to densely hairy. Pod descending, terete to slightly tetragonal, 22-27 mm long, 2.2-2.5 mm wide, brown, strigose, glabrescent; hairs sparse, appressed; apex shortly beaked (beak 1.5-2.5 mm long); endocarp not spotted; seeds cuboid, 7-10 per fruit, 1.3-1.6 mm long, 1-1.4 mm wide.

Notes: this species was for a long time considered a synonym of I. spicata until Du Puy et al. (1993) clarified the distinctions between the two species. Of the two, this appears to be the species definitely implicated in stock poisoning. The description given by Morton (1989) is certainly of this species, which was responsible for 'Grove Poisoning' of horses in Florida. Everist (1974) gives a full account of the occurrences of poisoning in Australia and of the toxic principle, indospicine, an analogue of the amino acid arginine. I. spicata is also naturalised in Australia (see below). References to I. spicata as a weed in Australia (Lazarides et al. 1997) would apply to this species as well.

See Du Puy et al. (1993) for full synonymy.

Distribution and habitat: only recorded from north Queensland, on the Atherton Tableland, from disturbed sites. The natural range of the species is Africa to Asia, but it is also naturalised in the West Indies, the southern United States and South America.

Selected Specimen: Queensland: Cook: Ball Rd, Malanda, Doherty s.n., 28 July 1965 (BRI).

Indigofera linnaei Ali, Bot. Not. 111: 549 (1958)

Hedysarum prostratum L., Syst. Nat., ed 12, 2: 496 (1767); Mant. 1: 102 (1767)

Lectotype (see Rudd 1991: 120): Burman, Fl. Indica, 168, t. 55, f. 1 (1768)

Anila prostrata (L.) Kuntze, Rev. Gen. Pl. 2: 938 (1891) 
Indigofera prostrata (L.) Domin, Biblioth. Bot. 89: 187 (1926) nom. illeg. non Willd. (1805) nec DC. (1825) nec Roxb. (1832) nec Wight \& Arn. (1834)

Indigofera enneaphylla L., Mant. 2: 272 (1771) nom. illeg. (see Ali 1958: 551)

I. dominii Eichler, Fl. S. Austral., ed. 2, suppl. 190 (1965) nom. superfl.

Illustration: Gardner and Bennetts (1956) plate xliii, as I. enneaphylla; Everist (1974) plate 25; Cunningham et al. (1981: 398) photo, as I. dominii; Jessop and Toelken (1986) fig. 309B; Urban (1990: 96) photo; Hacker (1990: 183) photo; Anderson (1993: 166) photo; Milson (1996: 49) photo.

Prostrate to spreading, perennial herb, $0.05-0.3 \mathrm{~m}$ high, to $0.7 \mathrm{~m}$ wide, with taproot; young stems slightly ridged (becoming obvious on older stems), green to white, strigose to pubescent with dense, appressed to spreading, equally biramous hairs. Leaves pinnate, (5-)7-9(-13) leaflets; stipules triangular with linear, drawn-out tip and thin scarious margin, (2-)3-7 mm long, pubescent, not spinescent, often persistent; petiole 1-4 mm long; rachis furrowed or flattened; multicellular hairs at the base of the petiolule absent. Leaflets mostly alternate; stipellae absent or very inconspicuous, $0.1-0.5 \mathrm{~mm}$ long; lamina obovate, (4.5-)5-15(-23) mm long, (1.0-)1.5-7(-10) mm wide; upper surface green to grey, with sparse to dense, appressed to spreading hairs; lower surface green to grey, with moderately dense to dense, appressed to spreading hairs; apex obtuse and mucronate, emarginate or rarely acute; veins not prominent. Inflorescences (3-)5-20(35) $\mathrm{mm}$ long, generally shorter than the leaf; peduncle $0.5-2(-13) \mathrm{mm}$ long; bracts ovate to triangular, $1.5-3.5 \mathrm{~mm}$ long, with scarious margins; flowers red; pedicel $0.5 \mathrm{~mm}$ long. Calyx 2.5-5 mm long; lobes unequal or subequal, longer than the length of the tube, covered with moderately dense to dense, grey, white or pale brown, appressed to shortly spreading, very unequal biramous hairs. Standard red, obovate, 3-5 mm long, 2.3-3.3 mm wide. Wings oblong to spathulate, 3.5-5 mm long, 0.7-1.2 mm wide. Keel 3.5-4.5 mm long, 0.7-1.2 $\mathrm{mm}$ deep; lateral pockets $0.3-0.6 \mathrm{~mm}$ long; apex beaked to acute; glabrous. Staminal tube (2.0-)2.5-3.2 mm long, colourless. Ovary densely hairy. Pod ascending, shortly cylindrical, (2.5-)4-8(-10.5) $\mathrm{mm}$ long, 2-2.5 mm wide, white to grey or yellowish and brown, strigose to pubescent; hairs moderately dense to dense, appressed to spreading; apex shortly pointed; endocarp not spotted; seeds (1-)2(-4) per fruit.

Notes: this plant is usually \pm prostrate but, as pointed out by Gardner and Bennetts (1956), it is occasionally found with erect stems up to $45 \mathrm{~cm}$ high. They cite a record from near Halls Creek. In the present study, the first author found erect plants at only one location, also in the Kimberley region (Wilson 209). Seed number is almost always 2; the single, undated collection with about 4 seeds per fruit seems to have been collected in the late $19^{\text {th }}$ Century at Peak Downs (Burkitt s.n. MEL586548, 586552).

Gardner and Bennetts (1956) and Everist (1974) give a detailed account of the toxicity of this species, which causes 'Birdsville Disease' in horses, the symptoms of which include weight loss, general weakness and progressive loss of coordination. The causative agent for this disease is uncertain but it is known that I. linnaei, like $I$. spicata, produces indospicine and this may interfere with utilisation of arginine by the animal. Although indospicine is a known hepatotoxin and accumulates in the liver of horses, it does not produce liver disease but it is known to cause liver necrosis in dogs fed on horse meat (Pollitt et al. 1999). 
Distribution and habitat: Queensland, New South Wales, South Australia, Western Australia, and the Northern Territory. Recorded as growing on most substrates, particularly on sand in open areas, grassland or woodland, and particularly on disturbed sites like roadsides. Also found in Pakistan, India, Sri Lanka, Burma, Thailand, Vietnam, Indonesia and New Guinea. Indigofera linnaei is considered a weed in Australia (Lazarides et al. 1997).

Selected specimens: Queensland: Burke: 20 miles [c. $32 \mathrm{~km}$ ] SW of Cloncurry township, Lazarides 4407, 16 Mar 1954 (AD, BRI, CANB, DNA, MEL). Burnett: 'Brian Pastures', Gayndah, McKee 10205, 3 Apr 1963 (BRI, NSW). Cook: 7 km from Kennedy crossing on Fairview-Kimba road on track to King River outstation, Clarkson 3239, 22 Apr 1980 (BRI, NSW). Gregory North: Carrandotta, Everist 3285, 27 Nov 1947 (BRI). Gregory South: South Galway Station, 60 miles [c. 96 km] SW of Windorah, Everist 4117, 7 Sep 1949 (BRI, DNA). Leichhardt: Orion Downs, Everist 4345, 20 June 1951 (BRI, CANB). Mitchell: 8.9 km S of Jundah turn-off on 'Warbreccan'-Windorah road, Wilson 396 \& Pickering, 22 Sep 1989 (NSW). Moreton: near Laidley, Blake 10407, 26 Jan 1936 (BRI, CANB). North Kennedy: Cardington, c. 40 miles [c. 64 km] S of Townsville, bank of Haughton River, Everist 5515, 11 May 1954 (BRI, CANB). Port Curtis: Apis Creek, Bruce Highway, $40 \mathrm{~km}$ W of Marlborough, Halliday 358, 5 Apr 1975 (BRI). South Kennedy: 8 km SE of Eungella Dam, Byrnes 3615 \& Clarkson, 6 Apr 1978 (BRI). Warrego: $22 \mathrm{~km} \mathrm{~N}$ of Charleville along road to Augathella, Purdie 186 \& Boyland, 25 Mar 1976 (BRI). Wide Bay: Mt Walsh, 6 km S of Biggenden, Crisp 2588 \& Ellyard, 28 May 1977 (BRI, DNA). New South Wales: North Coast: Copmanhurst, Rupp 2, Feb 1910 (NSW). North Far Western Plains: Berawinnia Downs, Milthorpe 5069 \& Cunningham, 30 Nov 1976 (NSW). North Western Plains: MacIntyre River, Yetman, Dunn 65, Plat \& Coveny, 28 Mar 1987 (NSW, BRI). South Australia: North-western: Ernabella Mission, Turvey s.n., 8 May 1963 (AD, DNA, NSW). Lake Eyre: Birdsville Track, near Mt Gason, c. 45 km SSW of Clifton Hills homestead, Crisp $39 \&$ Noble, 6 Apr 1969 (AD); Wintinna Creek, between Coober Pedy and Welbourn Hill, Beauglehole 44369, 21 May 1974 (MEL). Western Australia: Carnarvon: 1 mile [c. $1.6 \mathrm{~km}$ ] E of Yanrey HS, turn-off to Bullara, George 1175, 29 Aug 1960 (PERTH). Dampier: 4 km S of Cape Bertholet, Dampierland, Kenneally 6024, 19 Apr 1977 (CANB, PERTH). Fitzgerald: 3.7 km E of Fletcher River crossing, Gibb River Road, Wilson 209, 10 May 1988 (NSW, PERTH, B, K). Fortescue: 8.1 km WNW of East Harding River, North West Coastal Highway, Wilson 1006, Rowe \& Mitchell, 10 Sep 1991 (NSW, PERTH, PRE). Gardner: Osmond Creek below junction with Red Rock Creek, Bungle Bungle NP, Menkhorst 911, 21 June 1989 (DNA). Hall: Duncan Highway, 134 km E of Halls Creek, Beauglehole 51231, 22 May 1976 (PERTH). Keartland: Rudall River, George 10644, 18 May 1971 (CANB, PERTH). Northern Territory: Barkly Tableland: 9 miles [c. $14.4 \mathrm{~km}$ ] W of Alroy Downs, Chippendale NT 5372, 8 Mar 1959 (AD, BRI, CANB, DNA, NSW); Lorne Ck, 16 miles [25.6 km] N of Soudan, Chippendale NT 1851, 18 Mar 1956 (BRI, DNA, MEL, NSW). Central North: 20.8 miles [c. 33.7 $\mathrm{km}]$ N of Georgina Downs homestead, Chippendale NT 3821, 1 Oct 1957 (AD, DNA, NSW); Singleton, 240 miles [c. 384 km] N of Alice Springs, Everist 4234, 28 Jan 1950 (BRI, DNA. MEL). Central South: Kings Canyon, Latz 262, 10 Dec 1968 (DNA, NSW, K, MO); Blue Grass Bore, 15 miles [c. 24 km] SW Milton Park homestead, Nelson NT 11961, 23 Feb 1966 (AD, BRI, DNA, NSW). Darwin \& Gulf: 58 miles [c. 93 km] NE of Beetaloo homestead, Chippendale NT 5497, 10 Mar 1959 (AD, BRI, DNA). Victoria River: 13 miles [c. 20.8 km] N Montejinni homestead, Chippendale NT 6923, 11 May 1960 (BRI, DNA, NSW).

${ }^{*}$ Indigofera oblongifolia Forssk., Fl. Aegypt. Arab. 137 (1775)

Type: [Yemen] Lohajae, Forsskål s.n. (not extant, fide Hepper \& Friis 1994)

Neotype (see Ali 1958:546): Aegyptus superior, E. Boissier, Feb. 1846 (K, n.v.)

Illustration: Andrews (1952) fig. 81. 
Erect shrub, 0.5-2 $\mathrm{m}$ high, with woody rootstock; young stems ridged, grey to green, strigose with dense to very dense, appressed, equally biramous hairs. Leaves variable, with 1-3(-4) leaflets, unifoliolate, trifoliolate, or pinnate; stipules narrowly triangular, 2-6 mm long, pubescent, not spinescent, not persistent; petiole 2-6(-10) mm long; rachis furrowed; multicellular hairs at base of leaflets sparse, inconspicuous, pale orange, pointed-linear. Leaflets alternate; stipellae absent or inconspicuous and $0.2-0.5 \mathrm{~mm}$ long; lamina of lateral leaflets elliptical to obovate, (8-)10-18 $\mathrm{mm}$ long, 3.5-6 mm wide; terminal or unifoliolate leaflets elliptical or obovate, $15-30 \mathrm{~mm}$ long, 5-9 mm wide; upper surface grey to green, with sparse to moderately dense, appressed hairs; lower surface grey to green, generally paler than above, with moderately dense, appressed hairs; apex acute or obtuse and mucronate; veins not prominent. Inflorescences (15-)30-105 mm long, longer than leaves; peduncle 3-7 mm long; bracts ovate, $1 \mathrm{~mm}$ long; flowers red, the colour variable with pink and yellow-green shades; pedicel mostly $0.7-0.9 \mathrm{~mm}$ long. Calyx 1.5-2.5 mm long; lobes equal or unequal, less than to longer than the length of the tube and covered with moderately dense to dense, grey, appressed hairs. Standard with red striations, ovate to obovate, 5-6 mm long, 4-4.5 mm wide. Wings pink-red, spathulate to narrowly obovate; $4.5-5 \mathrm{~mm}$ long, $1.5-2 \mathrm{~mm}$ wide. Keel greenish but flushed pink in the upper part, 4.5-6.5 $\mathrm{mm}$ long, 1.5-2 $\mathrm{mm}$ deep; lateral pockets 1-1.3 mm long; apex acute to rounded; glabrous to sparsely hairy with hyaline to grey hairs at the tip and along the bottom; margin variably ciliate. Staminal tube 4-5 mm long, colourless. Ovary moderately to densely hairy. Pod spreading to deflexed, terete and torulose, crescent shaped, (6-)10-19 mm long, $2 \mathrm{~mm}$ wide, brown, strigose; hairs moderately dense, appressed; apex acute or shortly beaked; endocarp not spotted; seeds (1-)4-6 per fruit.

Notes: see de Kort and Thijsse (1984) for full synonymy. These authors, and a few others, suggest that the type of this species is amongst Forsskall's collections at Copenhagen but Hepper and Friis (1994) assert that a Forsskål specimen of this species cannot be found there. Further enquiries at Copenhagen have confirmed that no Forsskål material of this species has been found since 1994 (Olof Ryding pers. comm. 2007). Ali (1958) designated a neotype.

Distribution and habitat: the natural range of this species is from northern tropical Africa to northern India and Sri Lanka; it is also recorded from Java where it is probably introduced. It has become naturalised in the vicinity of Port Hedland and De Grey Station in the Fortescue region of Western Australia where it occurs in gravelly and sandy alluvial soils. Label information with the most recent collection indicates that this species is actively spreading and is abundant on roadsides and in disturbed areas.

Selected Specimens: Western Australia: Fortescue: Along main road between Port Hedland \& South Hedland, Mitchell 2451, 25 Apr 1992 (NSW); c. 18 km S of De Grey Homestead on main road on W side of river, Mitchell 3566, 27 Apr 1994 (NSW, PERTH); De Grey River on Northern Coastal Highway, Allen s.n., 2 Aug 2007 (BRI, NSW).

${ }^{\star}$ Indigofera sessiliflora DC., Prod. 2: 228 (1825)

Holotype: Senegal, Perrottet s.n. (P, n.v.). Isotype: $\mathrm{BM}, n . v$.

Anila sessiliflora (DC.) Kuntze, Rev. Gen. Pl. 2: 940 (1891)

Spreading or prostrate, annual or short lived perennial herb, $0.05-0.15 \mathrm{~m}$ high, with taproot; young stems ridged, green, hirsute with dense, somewhat spreading, equally or unequally biramous hairs. Leaves pinnate, 3-7 leaflets; stipules triangular, $2.5-5 \mathrm{~mm}$ 
long, pubescent, not spinescent, not persistent; petiole 4-7 mm long; rachis furrowed; multicellular hairs at the base of the petiolule absent. Leaflets alternate or sub-opposite; stipellae absent; lateral leaflets elliptical to obovate, 5-16 mm long, 2.5-6 mm wide; upper and lower surface green to grey, with sparse to moderately dense, appressed to shortly spreading hairs; apex acute or obtuse and mucronate; veins not prominent. Inflorescences 5-13 $\mathrm{mm}$ long, shorter than leaves; peduncle 0-1 mm long; bracts narrowly triangular, 0.8-1.2 mm long; flowers red; pedicel 0-0.5 mm long. Calyx 2.5$3.5 \mathrm{~mm}$ long; lobes equal, much longer than the length of the tube and covered with moderately dense to dense, grey, shortly spreading hairs. Standard red, obovate, 2.5$3 \mathrm{~mm}$ long, $1.3-1.9 \mathrm{~mm}$ wide. Wings oblong to narrowly obovate, $2.5-2.8 \mathrm{~mm}$ long, $0.6 \mathrm{~mm}$ wide. Keel $2.7-3 \mathrm{~mm}$ long, $0.8-0.9 \mathrm{~mm}$ deep; lateral pockets $0.3-0.5 \mathrm{~mm}$ long; apex acute; glabrous. Staminal tube 1.5-1.8 mm long, colourless. Ovary moderately hairy. Pod ascending, shortly cylindrical and slightly torulose, 3-7 mm long, $1.5 \mathrm{~mm}$ wide, grey to pale brown, strigose; hairs sparse to moderately dense, appressed to shortly spreading; apex shortly pointed; endocarp not spotted; seeds \pm spherical, $2-4$ per fruit.

Distribution and habitat: only recorded from Western Australia where it appears to be a relatively recent introduction, perhaps from a ship's ballast. This species is naturalised at Port Hedland where it has been found along the foreshore and on road edges on sandy soils; it has the potential to become a serious weed. It is native to western and north-eastern Africa, through Saudi Arabia to Pakistan and north-western India.

Other specimens examined: Western Australia: Fortescue: Spoil Bank Recreation Area, Wilson 1001 \& Rowe, 8 Sep 1991 (NSW, CANB, K, KARR, PERTH, UPS); between foreshore and main road opposite Port Hedland hospital, Mitchell 2452, 25 Apr 1992 (NSW, PERTH).

${ }^{\star}$ Indigofera spicata Forssk., Fl. Aegypt. Arab. 138 (1775)

Holotype: [Yemen] Bolgose, Forsskål 1356, March 1763 (C, fide Hepper and Friis 1994)

Anila ? spicata (Forssk.) Kuntze, Rev. Gen. Pl. 2: 940 (1891)

Illustration: Hacker (1990: 186) photo; Du Puy et al. (1993) Fig. 1, A-E.

Prostrate perennial herb, up to $0.5 \mathrm{~m}$ high, with woody rootstock; young stems ridged (flattened when young), green or yellowish, strigose with sparse, hyaline to white appressed, equally biramous hairs. Leaves pinnate, 5-7 leaflets, 12-40 mm long; stipules triangular with scarious margins, (2.5-)3.5-5.5(-6.5) $\mathrm{mm}$ long, glabrescent, not spinescent, persistent; petiole 2-6 mm long; rachis furrowed; multicellular hairs at the base of the petiolule absent. Leaflets alternate; stipellae absent or inconspicuous, 0.2-1.2 mm long, membranous, some dividing into 2 or 3 segments; leaflets obovate, (3-)4-11(-16) mm long, 2.5-8(-10) mm wide; upper surface dull green, glabrous or with sparse, appressed hairs; lower surface green with sparse to moderately dense, appressed hairs; apex obtuse (with a short mucro); veins not prominent. Inflorescences 30-65(-80) $\mathrm{mm}$ long, longer than leaves; peduncle 15-20(-25) $\mathrm{mm}$ long; bracts triangular (margin scarious), 1.2-2 mm long; flowers pink to orange-red; pedicel 0.3-0.7 mm long. Calyx 2-3 mm long; lobes subequal, longer than the length of the tube and covered with sparse to moderately dense, white, appressed hairs. Standard reddish, obovate, 3.8-4.9 $\mathrm{mm}$ long, 2.5-3.7 $\mathrm{mm}$ wide; hairs sparse (few at apex only), hyaline to white; apex obtuse. Wing oblong to spathulate, $3.7-4.5 \mathrm{~mm}$ long, $0.5-1.1 \mathrm{~mm}$ wide. Keel $3.9-4.4 \mathrm{~mm}$ long, $1-1.3 \mathrm{~mm}$ deep; lateral pockets $0.3-0.5 \mathrm{~mm}$ long; apex 
acute; glabrous or with sparse, hyaline hairs at the tip. Staminal tube 2.3-3.2 mm long, colourless. Ovary moderately to densely hairy. Pod descending, terete (often torulose when young), 10-18 $\mathrm{mm}$ long, 1.5-2 $\mathrm{mm}$ wide, yellowish and brown, strigose to glabrescent; hairs sparse, appressed; apex shortly pointed (to $0.5 \mathrm{~mm}$ long); endocarp not spotted; seeds cuboid, 4-8 per fruit, 1.3-1.6 mm long, 1-1.4 mm wide.

Notes: see Du Puy et al. (1993) for full synonymy. As far as we can determine, this species has not definitely been implicated in stock poisoning, all documented occurrences apparently referring to I. hendecaphylla.

Distribution and habitat: this species is a native of Africa but has been recorded as naturalised in a few areas of southern Queensland, near Coffs Harbour in northern New South Wales, and in Katherine, Northern Territory, where it occurs in open, disturbed areas. Some of these plants may be descended from plants grown in field trials as a potential fodder species.

Selected specimens: Queensland: Moreton: St Lucia, Brisbane, Pedley 5372, 3 May 1987 (BRI, MEL, NSW). Wide Bay: old North Deep Creek pasture site, Widgee Shire, Cook s.n., 16 Jan 1980 (BRI). New South Wales: North Coast: Mid Sapphire Beach, N of Coffs Harbour, Benwell s.n., Feb 2005 (NSW). Northern Territory: Katherine Research Station, Mitchell 6384, 16 Oct 2000 (NSW).

\section{Acknowledgments}

We wish to thank the heads of the herbaria cited for loans of herbarium material. Our thanks to Brian Schrire (K) for advice and help with various enquiries; to Stephen van Leeuwen, Andrew Mitchell, John Clarkson, Surrey Jacobs, Andrew Benwell and Chris Puttock, for assistance in the field and/or for the gift of specimens. Particular thanks go to Jeremy Bruhl (Australian Botanical Liaison Officer, Kew, 2007-8) for photographing portions of the type of Indigofera trifoliata, to Charlie Jarvis (LINN) and to Jonathan Gregson and John Hunnex (BM) for facilitating this. This study was supported by a grant from the Australian Biological Resources Study.

\section{References}

Albrecht DE, Duguid AW, Latz PK, Coulson H \& Barritt MJ (1997) Vascular Plant Checklist for the Southern Bioregions of the Northern Territory: Nomenclature, Distribution and Conservation Status. (Parks and Wildlife Commission of the Northern Territory).

Ali SI (1958) Revision of the genus Indigofera L. from W. Pakistan and N.W. Himalayas. Botaniska Notiser 111: 543-577.

Anderson E (1993) Plants of Central Queensland: their identification and uses. (Department of Primary Industries: Brisbane).

Andrews FW (1952) The Flowering Plants of the Anglo-Egyptian Sudan, vol. 2. (Buncle: Arbroath, Scotland).

Banks J \& Solander D (1900) Illustration of the Botany of Captain Cook's Voyage around the World in H.M.S. Endeavour, vol. 1. (Trustees of the British Museum: London).

Bunce D (1859) Travels with Dr. Leichhardt. (Reprint 1979, Oxford University Press: Melbourne).

Cunningham GM, Mulham WE, Milthorpe PE \& Leigh JH (1981) Plants of Western New South Wales. (Soil Conservation Service of New South Wales: Sydney). 
De Kort I \& Thijsse G (1984) A revision of the genus Indigofera (Leguminosae: Papilionoideae) in Southeast Asia. Blumea 30: 89-151.

Du Puy DJ, Labat J-N \& Schrire BD (1993) The separation of two previously confused species in the Indigofera spicata complex (Leguminosae: Papilionoideae). Kew Bulletin 48: 727-733.

Endo Y \& Ohashi H (1998) Diagnostic characters and distribution of Indigofera pedicellata Wight \& Arn. (Leguminosae). Journal of Japanese Botany 73: 67-75.

Everist SL (1974) Poisonous Plants of Australia. rev. ed. (Angus \& Robertson: Sydney).

Gardner CA \& Bennetts HW (1956) The Toxic Plants of Western Australia. (West Australian Newspapers Ltd.: Perth).

Hacker JB (1990) A Guide to Herbaceous and Shrub Legumes of Queensland. (University of Queensland Press: St Lucia).

Hepper FN \& Friis I (1994) The Plants of Pehr Forsskål's 'Flora Aegyptiaco-Arabica'. (Royal Botanic Gardens: Kew).

IUCN (2001) IUCN Red List Categories and Criteria, version 3.1. (IUCN: Gland and Cambridge)

Jessop JP \& Toelken HR (1986) Flora of South Australia, vol. 2. (SA Government Printing Division: Adelaide).

Lazarides M, Cowley K \& Hohnen P (1997) CSIRO Handbook of Australian Weeds. (CSIRO Publishing: Collingwood).

Milson J (1996) Plant Identification in the Arid Zone. (Department of Primary Industries: Brisbane).

Morton JF (1989) Creeping Indigo (Indigofera spicata Forsk.) (Fabaceae) - a hazard to herbivores in Florida. Economic Botany 43: 314-327.

Pollitt S, Hegarty MP \& Pass MA (1999) Analysis of the amino acid indospicine in biological samples by high performance liquid chromatography. Natural Toxins 7: 233-240.

Rudd VE (1991) Tribe Indigofereae. Pp. 114-135 in Dassanayake MD \& Fosberg FR (eds), Revised Handbook to the Flora of Ceylon, vol. 7. (Amerind Publishing: New Delhi).

Schrire BD (1995) Evolution of the tribe Indigofereae (Leguminosae Papilionoideae). Pp. 161244 in Crisp MD \& Doyle JJ (eds), Advances in Legume Systematics, vol. 7. (Royal Botanic Gardens: Kew).

Stafleu FA \& Cowan RS (1988) Taxonomic Literature, ed. 2, vol. 7 (Junk: The Hague).

Turland NJ \& Jarvis CE (1997) Typification of Linnaean specific and varietal names in the Leguminosae (Fabaceae). Taxon 46: 457-485.

Urban A (1990) Wildflowers and Plants of Central Australia. (Southbank Editions: Port Melbourne).

Wilson PG \& Rowe R (1994) The Indigofera trita complex (Fabaceae: Indigofereae) in Australia. Telopea 5: 637-645.

Wilson PG \& Rowe R (2004) A revision of the Indigofereae (Fabaceae) in Australia. 1. Indigastrum and the simple or unifoliolate species of Indigofera. Telopea 10:651-682.

Manuscript received 29 January 2008, accepted 20 May 2008 